\title{
Ülkelerin Afet Riski Performans Değerlendirmesi: Bulanık Mantık Uygulaması
}

\author{
Ali Erkan KARAMAN"1, Barış ÖZKUL ${ }^{1}$ \\ ${ }^{1}$ Balıkesir Üniversitesi, Mühendislik Fakültesi, İnşaat Mühendisliği Bölümü, Balıkesir
}

Geliş tarihi: 20.12.2020

Kabul tarihi: 31.03 .2021

Öz

Bu çalışmada; afet öncesi ve afet sonrasını kapsayan afet yönetimi süreci incelenmiştir. Ülkelerin afet yönetimi performanslarını diğer ülkelerle karşılaştırmalarını sağlayacak bir model geliştirilerek örnek bir uygulama sunulması amaçlanmıştır. Çalışmanın örneklemi 4 farklı ülke için alanında uzman 5 akademisyenin görüşü alınarak belirlenmiştir. Ölçülen risk değerleri bulanık sayılara dönüştürülerek ana risk ve alt risk değerleri oluşturulmuştur. Ülkelerin afet risk yönetimi performansını karşılaştırmak için bulanık ağılıklı ortalama (FWA) algoritması kullanılmıştır. Elde edilen sonuçlar ülkelerin afet sonrası aşamada afet öncesi aşamaya göre daha başarılı olduğunu ve örneklemde simgesel olarak gösterilen A ülkesinin risk performans değeri en yüksek olduğunu göstermiştir.

Anahtar Kelimeler: Doğal afetler, Risk performans değerlendirmesi, Bulanık mantık

\section{Disaster Risk Performance Assessment of Countries: Application of Fuzzy Logic}

\begin{abstract}
In this study; The disaster management process, including pre-disaster and post-disaster, has been examined. It is aimed to present a model application by developing a model that will enable countries to compare their disaster management performances with other countries. The sample of the study was determined for 4 different countries by taking the opinions of 5 academicians who are experts in their fields. The main risk and sub-risk values were created by converting the measured risk values into fuzzy numbers. It uses fuzzy weighted average (FWA) algorithm to compare disaster risk management performance of countries. The results have shown that countries are more successful in the post-disaster phase than the pre-disaster phase, and the risk performance value of country A, which is symbolically shown in the sample, is the highest.
\end{abstract}

Keywords Natural disasters, Disaster assessment, Risk performance assessment, Fuzzy logic

"Sorumlu yazar (Corresponding author): Ali Erkan KARAMAN, ekaraman@balikesir.edu.tr 


\section{INTRODUCTION}

According to Manilofia [1] and $\mathrm{Xu} \& \mathrm{Lu}$ [2], the concept of disaster management consists of two stages: "preparedness" before the disaster and "rehabilitation" after the disaster. According to the Souza Wisconsin University Disaster Management Center, disaster management is defined as "the interval of activities designed to ensure control over the disasters and emergencies and protect the people under risk or decrease the risk." In order to assess the comprehensive application results, the phases before and after the disaster should be evaluated together to be able to take effective precautions against natural disasters. Although disaster management in its general meaning is assessed only for the after-disaster phase, the work to be conducted by the planner and the decisionmaking mechanisms regarding a decrease in the impact of disasters are very important in terms of relieving the destructive impact of disasters [3].

Crowe [4] observes that many countries have developed policies regarding the prevention of disasters by deriving lessons from repetition of the unforeseen disasters, and the developed policies are based on risk assessment tasks prepared for the prevention of disasters and decrease of their impacts. These tasks are separated into preventive precaution, mitigation, and preparedness activities. Preventive precaution and impact decrease activities contain the process of taking steps that will prevent the transformation of a possible natural phenomenon into a disaster. Preparedness activities include the planning of what the reaction will be in the event of a disaster and making these precautions a part of the country's strategic plan [1]. When the literature is examined, it is seen that there are many studies conducted regarding disaster management [5-8].

In this study, the performance of risk management for natural disasters was examined in two steps, before the disaster and after the disaster, using the fuzzy logic method. This method was applied to four countries labeled A, B, C, and D that are acknowledged to have different development levels from one another.

\section{NATURAL DISASTERS}

According to Enarson [9], it is impossible to prevent natural phenomena, but it is possible to take various precautions before such phenomena turn into natural disasters. Natural phenomena have the risk of environmental distortion and the risk of damage to all living beings. The impact of natural phenomena on humans in different geographical regions may be different within different socioeconomical, political, social, and cultural contexts.

The social, political, and economic impact of natural phenomena such as tornados, volcanic eruptions, earthquakes, and floods are not inevitable. Decreasing the impact of the natural phenomena and thus the damage risk levels for the people is a function of the stages of preventive precaution, decrease of impact, and preparedness. The perception of security has physical and social dimensions, but the most important goal is to ensure people's access to the survival and rescue resources.

Earthquakes, floods, droughts, and other natural dangers cause tens of thousands of deaths, hundreds of thousands of injuries, and billions of dollars of economic losses every year around the world. EM-DAT, a global disaster database kept by the Center of Research for the Epidemiology of Disasters, records 600 disasters worldwide every year [10]. Dilley [11] has noted that disasters form an important risk resource for the poor, and they terminate the development gains and accumulated riches of developing countries.

An earthquakes is a natural disaster that can kill thousands of people in a few minutes, the impact of which are felt for weeks and years, and may cause very serious financial damage to buildings and infrastructure. Thousands of people lose their lives due to earthquakes every year. Some of the examples from the last 20 years include the following: 70,000 people lost their lives in in the Sichuan earthquake in 2008 that measured 8.0 on the Richter scale, 2,700 people lost their lives in the Algerian earthquake in 2003 that measured 6.8 
on the Richter scale, and 17,480 people lost their lives in the Marmara earthquake in Turkey in 1999 $[12,13]$. According to OECD [14], earthquakes are one of the most important natural disasters resulting with a loss of life of approximately 60,000 people per year worldwide, and approximately $90 \%$ of the earthquakes occur in developing countries. In most of the earthquakes, the loss of lives is related to the collapse of building or damage to structures. For example, hundreds of thousands of buildings collapsed in the 2008 Sichuan earthquake, including many public buildings such as schools and hospitals. In addition to the loss of people, the financial cost of this physical destruction is also important. It is estimated that the cost to the state economy of Turkey of the 1999 Marmara earthquake was approximately 20 billion dollars [15].

\section{MANAGEMENT OF NATURAL DISASTERS}

The pre-disaster phase is the "relatively normal" period of peace in any region in which the probability of disaster is high and where a damaging natural phenomenon will be seen sooner or later. This phase should be separated into prevention, mitigation, and preparedness activities. Prevention and mitigation activities are the precautions taken to decrease the probability of a disaster or the impact of an inevitable disaster. Normally; these precautions should be a part of the development program of the countries $[2,16]$. The prevention stage and mitigation activities are defined by Sena and Michael [17] as a continuous action to decrease or terminate the danger of possible disaster to humans and properties and the impact of such a disaster. The function of the prevention and mitigation activities is different from other emergency management disciplines because they include sudden interventions in response to the dangers within these activities or long-term preparedness solutions to decrease the risk instead of short-term development at the moment of a danger. Preparedness specifies the steps necessary at every level to prevent damage to property and to save lives when a disaster comes. Establishment of pre-disaster organizations, public awareness programs, training of first aid staff, establishment of warning systems, the stocking of food and medical supplies, and making plans at every level for a rapid reaction in the event of a disaster are important at the readiness stage of readiness. According to Manilofia [1], the disaster preparedness stage is a process that must be planned in advance. This process is conducted for the purpose of ensuring active movement of resources by making preliminary plans and preparedness efforts in the zone in which there is a probability of the occurrence for a natural phenomenon with the potential to turn into a disaster. Conducting the work of planning is extremely important for the transmission of the useful data because the communication infrastructure is the one mostly damaged at the moment of disaster. Another important issue is that the transportation services that will provide movement of the necessary materials or personnel in the rescue work should be planned. The teams that will intervene at the moment of disaster should be coordinated and trained.

According to Abulnour [18], the post-disaster phase includes all the disaster management actions and activities that are implemented after a disaster event has occurred. The post-disaster phase could be subclassified into the phases of recovery, rehabilitation, reconstruction, and development. The post-disaster phase starts with a short-term intervention process in which intensive emergency operations are applied. This phase should not last longer than fourteen days and should be for saving lives, relieving the pain of survivors, terminating other threats regarding life and property, and learning the nature and scope of the disaster $[1,19]$.

\subsection{Disaster Risk Management Performance}

In this study, a fuzzy logic model has been used to determine disaster risk management performance, and this model consists of the concepts [18] revealed by the disaster management cycle. A series of assessment criteria expressed with $\left(\mathrm{C}_{\mathrm{i}}\right)$ were developed to determine the disaster risk management performance. As explained in the study, these assessment criteria are gathered under 
two main headlines: $\left(\mathrm{C}_{1}\right)$ as pre-disaster phase and $\left(\mathrm{C}_{2}\right)$ as post-disaster phase.

A hierarchical structure has been formed to measure the performance of natural disaster risk management. A two-level hierarchical structure of the disaster management cycle [20] was used in the formation of the hierarchical structure (Figure 1). The Level 1 risk management performance $\mathrm{C}_{\mathrm{i}}(\mathrm{i}=$ $1,2)$ was separated into two criteria, pre-disaster $\left(\mathrm{C}_{1}\right)$ and post-disaster $\left(\mathrm{C}_{2}\right)$. Level 2 consists of a sub-criterion series $\mathrm{C}_{\mathrm{ij}}(\mathrm{j}=1,2, \ldots \mathrm{k})$ specifying the number of the sub-criteria $\left(\mathrm{C}_{\mathrm{i}}\right)$ to measure each main criterion. The pre-disaster phase could be separated into three sub-criteria: prevention $\left(\mathrm{C}_{1.1}\right)$, mitigation $\left(\mathrm{C}_{1.2}\right)$, and preparedness $\left(\mathrm{C}_{1.3}\right)$. The post-disaster phase contains four sub-criteria: recovery $\left(\mathrm{C}_{2.1}\right)$, rehabilitation $\left(\mathrm{C}_{2.2}\right)$, reconstruction $\left(\mathrm{C}_{2.3}\right)$, and development $\left(\mathrm{C}_{2.4}\right)$.

The importance weight of each criterion was determined with verbal variables including low importance, medium importance, and very strong importance $[21,22]$. These verbal variables could be represented in a convenient way by using fuzzy triangular numbers. In other words, these verbal terms could be turned into fuzzy triangle numbers afterwards. Fuzzy triangle numbers represent the verbal importance of the ij criterion of the countries assigned by an $\mathrm{m}(\mathrm{m}=1,2 \ldots, \mathrm{n})$ assessor(s). The fuzzy average importance weight of the $\mathrm{ij}$ assessment criterion could be calculated with Equation 1 [22].

$$
W_{i j}=\left(\frac{1}{n}\right) \otimes \sum_{m=1}^{n} w_{i j, m}
$$

In this formula, indication " $\otimes$ " is the fuzzy multiplication operator. It also shows the average fuzzy importance weight of " $\mathrm{W}_{i j}, \mathrm{C}_{\mathrm{ij}}$ " criteria, and "n" shows the number of countries.

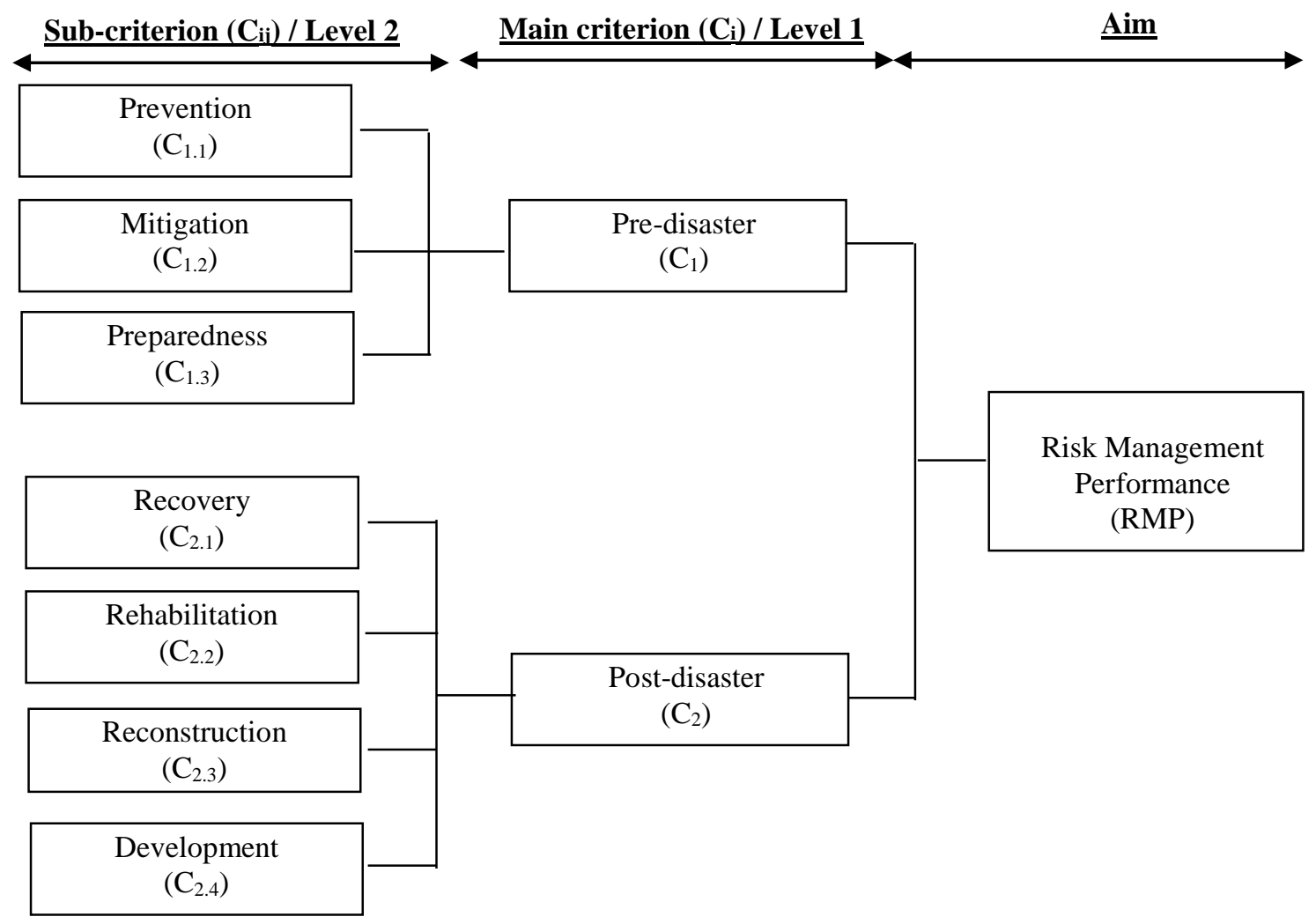

Figure 1. Hierarchical structure of the risk management performance 
The next step is the rating of the pre-disaster and post-disaster phases of the countries. The predisaster and post-disaster phases could be assessed by using a two-stage process: (1) development of a multi-item scale set or the measurement of each sub-criterion $\left(\mathrm{R}_{\mathrm{ij}}\right)$ and (2) rating of the success of the country on each item using the verbal variables. The use of multi-item scales for the measurement of each sub-criterion $\left(R_{i j}\right)$ increases the reliability of the rating process. The verbal variables used for the success of the rated country in each element are turned into fuzzy triangle numbers afterwards. The " $r_{i j, h}$ " value becomes the triangle fuzzy number representing the $(h=1,2, \ldots$, s) element measuring the performance rating of the sub-criterion ij. The " $\mathrm{S}$ " value is the element number used in the measurement of each subcriterion $\left(\mathrm{R}_{\mathrm{ij}}\right)$. The fuzzy average performance degree of the sub-criterion belonging to " $\mathrm{m}$ " country could be derived by using Equation 2 [22].

$$
R_{i j, m}=\left(\frac{1}{s}\right) \otimes \sum_{h=1}^{s} r_{i j, h}
$$

Risk management performances of the countries are the functions of the Level 1 criteria (main criteria) and Level 2 criteria (sub-criteria). Therefore, it is necessary to bond the fuzzy weights with the degrees of Level 1 and Level 2 criteria given in Figure 1 to determine this performance. This bonding process starts from the sub-criterion level (Level 2) and proceeds to the main criterion level (Level 1). The bonding of the average fuzzy importance weights $\left(\mathrm{W}_{\mathrm{ij}}\right)$ with the average fuzzy performance degrees $\left(\mathrm{R}_{\mathrm{ij}}\right)$ of Level 2 criteria $\left(\mathrm{C}_{\mathrm{ij}}\right)$ provides the fuzzy weighed average performance ratings $\left(\mathrm{R}_{\mathrm{i}}\right)$ of Level 1 criteria $\left(\mathrm{C}_{\mathrm{i}}\right)$. Similarly, the bonding of the average fuzzy importance weights $\left(\mathrm{W}_{\mathrm{i}}\right)$ and the fuzzy weighed average performance degrees $\left(\mathrm{C}_{\mathrm{i}}\right)$ of Level 1 criteria reveal the Fuzzy Risk Management Performance Index (FRMPI) [23,24].

The fuzzy weighed average (FWA) method is used to collect the average fuzzy performance rating of Level 1 and Level 2 and the average fuzzy importance weights. The fuzzy weighed average (FWA) method used to measure the fuzzy risk management performance index (FRMPI) of "m" country could be defined as using Equations 3 and 4 .

$$
\begin{aligned}
& R_{i, m}=\sum_{j=1}^{k} R_{i j, m} \otimes W_{i j} / \sum_{j=1}^{k} W_{i j} \\
& F R M P_{m}=\sum_{i=1}^{l} R_{i, m} \otimes W_{i} / \sum_{i=1}^{l} W_{i}
\end{aligned}
$$

Because there are fuzzy numbers and fuzzy arithmetical transactions in the formulas above, their solution is very difficult. Different algorithms $[21,22,25]$ have been suggested to calculate the fuzzy weighed average given in the equations below and to facilitate the fuzzy arithmetical transactions. The risk management performance assessment model given in this study adopts the algorithm of Kao and Liu [21] as the most efficient algorithm. This algorithm contains the solution with linear programing techniques by turning the solution of the fuzzy weighed average into a linear rational program with the $\alpha$-section method.

\subsection{A Sample Application Regarding the Suggested Model}

In this study, an application regarding the sampling of the usage of the model suggested to determine the risk management performance of the countries has been conducted. In this sample application, an earthquake has been chosen as the disaster type, and the risk management performances have been determined for four sample countries (A, B, C, D; n=4) with similarities in terms of "earthquake" disaster risk and carrying "high risk", but whose development level is different from one another. Country names were not used in this study and were coded alphabetically. Fault lines pass through these countries and their seismic characteristics are determined to be similar. The two most distinctive features among selected countries are the development level and population.

A Risk Management Performance Model (RMPM) has been prepared with the examination $[18,20]$ of the previous studies regarding the disaster 
management. The RMPM consists of two parts. The first part of RMPM contains a series of questions defining the importance of each criterion. In this part, ratings (from "totally unimportant," "quite unimportant," "unimportant," "barely important," "moderately important," "very important," to "extremely important) of each main criterion $\left(\mathrm{C}_{\mathrm{i}}\right)$ and each sub-criterion $\left(\mathrm{C}_{\mathrm{ij}}\right)$ have been requested from different assessors (the larger the number of assessors, the more objective the study will be). In the second part of the RMPM, there are items assessing the studies conducted by the countries regarding the pre-disaster and postdisaster phases.

The verbal responses of the assessors regarding the importance levels for each criterion in the first part have been turned into triangle fuzzy numbers. The triangle fuzzy numbers related to the verbal terms used to measure the relative importance of each criterion have been determined as (0.0-0.0-0.1),
$(0.0-0.2-0.4),(0.1-0.3-0.5),(0.2-0.4-0.6),(0.3-0.5-$ $0.7), \quad(0.4-0.6-0.8), \quad(0.5-0.7-0.9), \quad(0.6-0.8-1.0)$, (0.7-0.9-1.0), and (0.8-1.0-1.0). The fuzzy average importance degree of each criterion has been calculated with the use of Equation 1.

The triangle fuzzy numbers related to the verbal terms used to measure the relation with each criterion in the second part have been determined as $(0.0-0.2-0.4),(0.1-0.3-0.5),(0.3-0.5-0.7),(0.5-$ $0.7-0.9),(0.7-0.9-1.0)$, and (0.8-1.0-1.0). The fuzzy triangle numbers representing the decisions of each assessors for each criterion are bonded with the use of Equation 2. This transaction is conducted for the purpose of attaining the average fuzzy performance degrees corresponding to each subcriterion. Fuzzy average weights $\left(\mathrm{W}_{\mathrm{ij}}\right)$ of Level 2 criteria and the average fuzzy performance ratings of Level 2 criteria of the countries are given in Table 1.

Table 1. Fuzzy average points and the weights of sub-criteria

\begin{tabular}{|c|c|c|c|c|c|}
\hline \multirow{3}{*}{$\begin{array}{c}\text { Sub- } \\
\text { criteria }\end{array}$} & \multicolumn{4}{|c|}{ Countries } & \multirow{3}{*}{$\begin{array}{c}\text { Fuzzy average } \\
\text { weights } \\
\left(\mathrm{W}_{\mathrm{ij}}\right)\end{array}$} \\
\hline & A Country & B Country & C Country & D Country & \\
\hline & $\begin{array}{c}\text { Fuzzy average } \\
\text { points }\left(R_{i j}\right)\end{array}$ & $\begin{array}{c}\text { Fuzzy average } \\
\text { points }\left(R_{i j}\right)\end{array}$ & $\begin{array}{c}\text { Fuzzy average } \\
\text { points }\left(R_{i j}\right)\end{array}$ & $\begin{array}{c}\text { Fuzzy average } \\
\text { points }\left(R_{i j}\right)\end{array}$ & \\
\hline $\mathrm{C}_{1.1}$ & $\begin{array}{l}(0.500,0.700,0.900) \\
\end{array}$ & $(0.200,0.400,0.600)$ & $(0.180,0.380,0.580)$ & $(0.060,0.220,0.380)$ & $(0.520,0.720,0.920)$ \\
\hline $\mathrm{C}_{1.2}$ & $(0.600,0.800,0.980)$ & $(0.300,0.500,0.700)$ & $(0.240,0.440,0.640)$ & $(0.040,0.180,0.320)$ & $(0.340,0.540,0.740)$ \\
\hline $\mathrm{C}_{1.3}$ & $(0.460,0.660,0.860)$ & $(0.280,0.480,0.680)$ & $(0.260,0.460,0.660)$ & $(0.080,0.300,0.480)$ & $(0.300,0.500,0.700)$ \\
\hline $\mathrm{C}_{2.1}$ & $(0.580,0.780,0.960)$ & $(0.280,0.480,0.680)$ & $(0.340,0.540,0.740)$ & $(0.080,0.240,0.400)$ & $(0.660,0.820,0.980)$ \\
\hline $\mathrm{C}_{2.2}$ & $(0.480,0.680,0.880)$ & $(0.360,0.560,0.760)$ & $(0.240,0.440,0.640)$ & $(0.040,0.180,0.320)$ & $(0.460,0.660,0.860)$ \\
\hline $\mathrm{C}_{2.3}$ & $(0.520,0.720,0.920)$ & $(0.380,0.580,0.780)$ & $(0.280,0.480,0.680)$ & $(0.120,0.300,0.480)$ & $(0.440,0.640,0.840)$ \\
\hline $\mathrm{C}_{2.4}$ & $(0.560,0.760,0.960)$ & $(0.300,0.500,0.700)$ & $(0.300,0.500,0.700)$ & $(0.060,0.200,0.340)$ & $(0.360,0.560,0.760)$ \\
\hline
\end{tabular}

The FRMP (Fuzzy Risk Management Performance) represents the general disaster risk management performance of a country. Therefore; it is necessary to bond the fuzzy weight and ratings of Level 1 and Level 2 criteria (Table 1 and 2) of each country in a two-stage process. In this study, the commercial optimization software LINGO was used. At the first stage, the average fuzzy importance weights " $\mathrm{W}_{\mathrm{ij}}$ " and the average fuzzy performance degrees " $\mathrm{R}_{\mathrm{ij}}$ " of "Level 2" criteria were bonded with the use of Equation 3. This bonding process contains the turning of Equation 1 into a linear programing model and its solution $(\alpha=$ 0.00 and 1.00) with the use of the $\alpha$ section method.

Table 2. Fuzzy average points and the weights of main criteria

\begin{tabular}{|l|c|c|c|c|c|}
\hline \multirow{2}{*}{$\begin{array}{c}\text { Main- } \\
\text { Criteria }\end{array}$} & \multicolumn{4}{|c|}{ Countries } & \multirow{2}{*}{$\begin{array}{c}\text { Fuzzy average } \\
\text { weights }\left(\mathrm{W}_{\mathrm{i}}\right)\end{array}$} \\
\cline { 2 - 5 } & $\begin{array}{c}\text { A Country } \\
\text { points }\left(\mathrm{R}_{\mathrm{i}, \mathrm{A}}\right)\end{array}$ & $\begin{array}{c}\text { Fuzzy average } \\
\text { points }\left(\mathrm{R}_{\mathrm{i}, \mathrm{B}}\right)\end{array}$ & $\begin{array}{c}\text { Fuzzy average } \\
\text { points }\left(\mathrm{R}_{\mathrm{i}, \mathrm{C}}\right)\end{array}$ & $\begin{array}{c}\text { Fuzzy average } \\
\text { points }\left(\mathrm{R}_{\mathrm{i}, \mathrm{C}}\right)\end{array}$ & \\
\hline $\mathrm{C}_{1}$ & $(0.503,0.719,0.930)$ & $(0.237,0.453,0.666)$ & $(0.208,0.421,0.631)$ & $(0.054,0.230,0.412)$ & $(0.580,0.760,0.940)$ \\
\hline $\mathrm{C}_{2}$ & $(0.527,0.737,0.939)$ & $(0.316,0.528,0.739)$ & $(0.285,0.493,0.701)$ & $(0.068,0.231,0.404)$ & $(0.420,0.620,0.820)$ \\
\hline
\end{tabular}


The $C_{i}$ fuzzy average performance ratings $R_{i}$ of the Level 1 criteria of each country and the fuzzy importance weights of Level 1 criteria are given in Table 2. At the second stage, solutions were calculated for the Fuzzy Risk Management Performance (FRMP) values of each country and different $\alpha$-section $(\alpha=0.00$ and 1.00) values with the linear programing model given in Equation 4. These solutions emphasize the uncertainty degree of the country regarding the risk management performance for the sample countries.

The FRMP for four different countries is given in Table 3. For the probability level as $\alpha=0$, the risk management performance of the country examined in the case study is given in Figure 2. For instance, the FRMP value of A country is between 0.510 and 0.935 . This range specifies that the risk management performance value of A country will not be higher than 0.935 and lower than 0.510 . For the probability level as $\alpha=1.00$, the risk management performance of A country handled as the sample was calculated as 0.727 . This situation represents the highest possible value of the risk management performance for the related country. The FRMP values attained for four countries are given in Table 3. A five-point scale was formed in Figure 3 to interpret the attained FRMP values as very bad (0.0-0.1-0.3), bad (0.1-0.3-0.5), medium $(0.3-0.5-0.7)$, good $(0.5-0.7-0.9)$, and very good $(0.7-0.9-1.0)$.

Table 3. Fuzzy risk management performance (FRMP) of the countries

\begin{tabular}{|c|c|c|c|c|}
\hline & \multicolumn{4}{|c|}{ Countries } \\
\hline & A Country & B Country & C Country & D Country \\
\hline FRMP & $(0.510,0.727,0.935)$ & $(0.261,0.487,0.709)$ & $(0.232,0.453,0.672)$ & $(0.058,0.230,0.410)$ \\
\hline
\end{tabular}

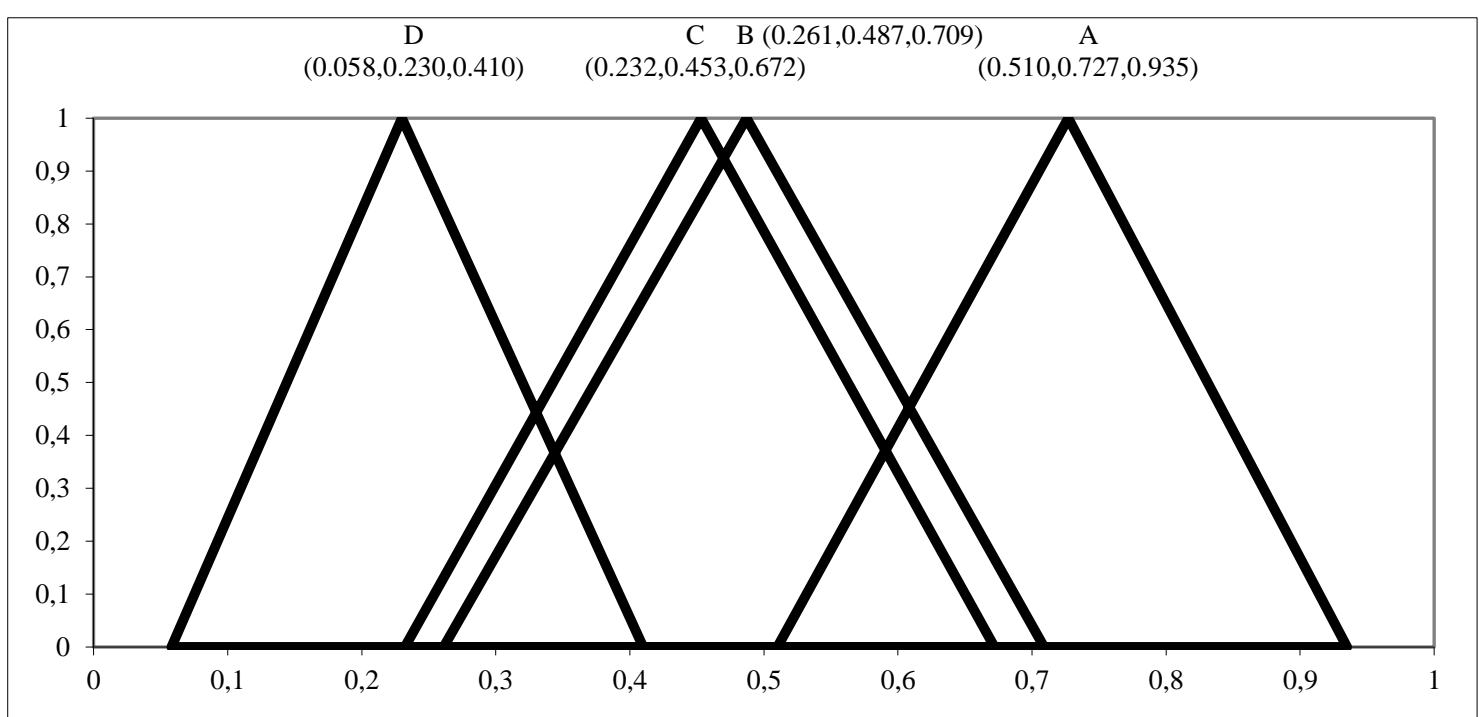

Figure 2. Fuzzy risk management performance (FRMP) of the countries

Figure 4 was obtained by combining the FRMP values shown in Figure 2 with the evaluation scale given in Figure 3. The attained results show that the most successful country in disaster risk management was A country, B and C countries were successful at the medium level, and D country showed an unsuccessful performance. 


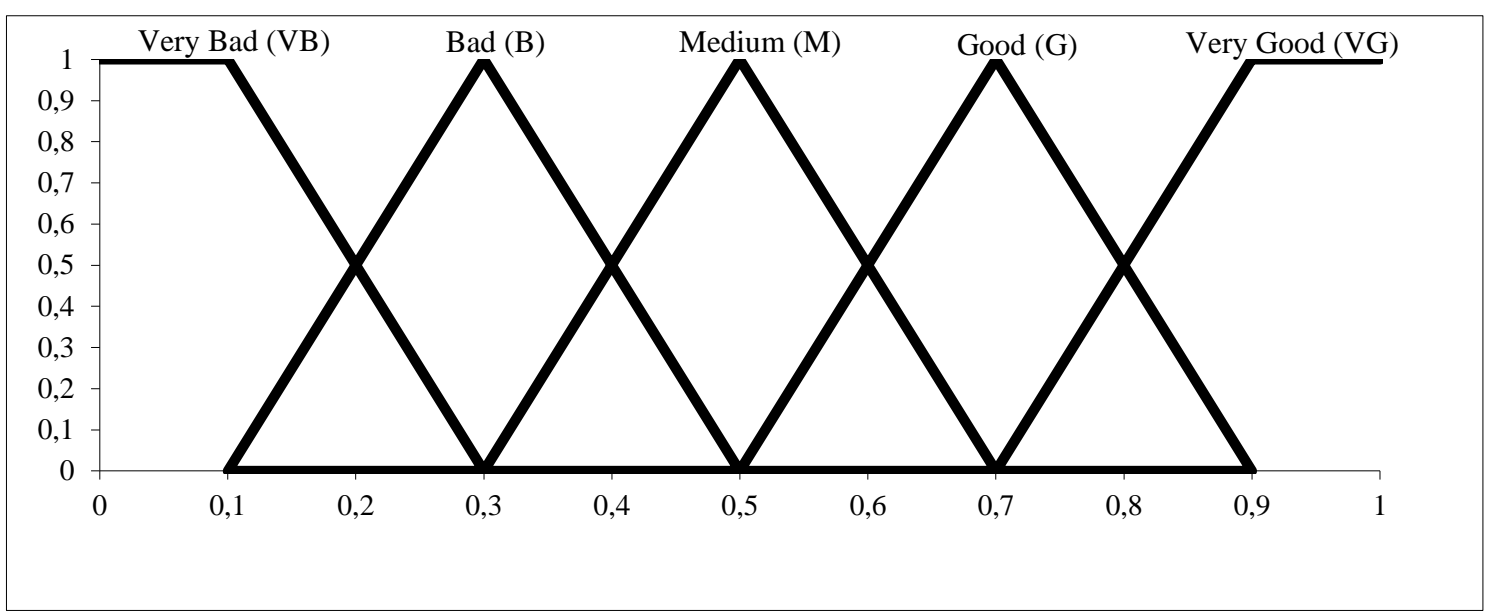

Figure 3. Fuzzy assessment scale

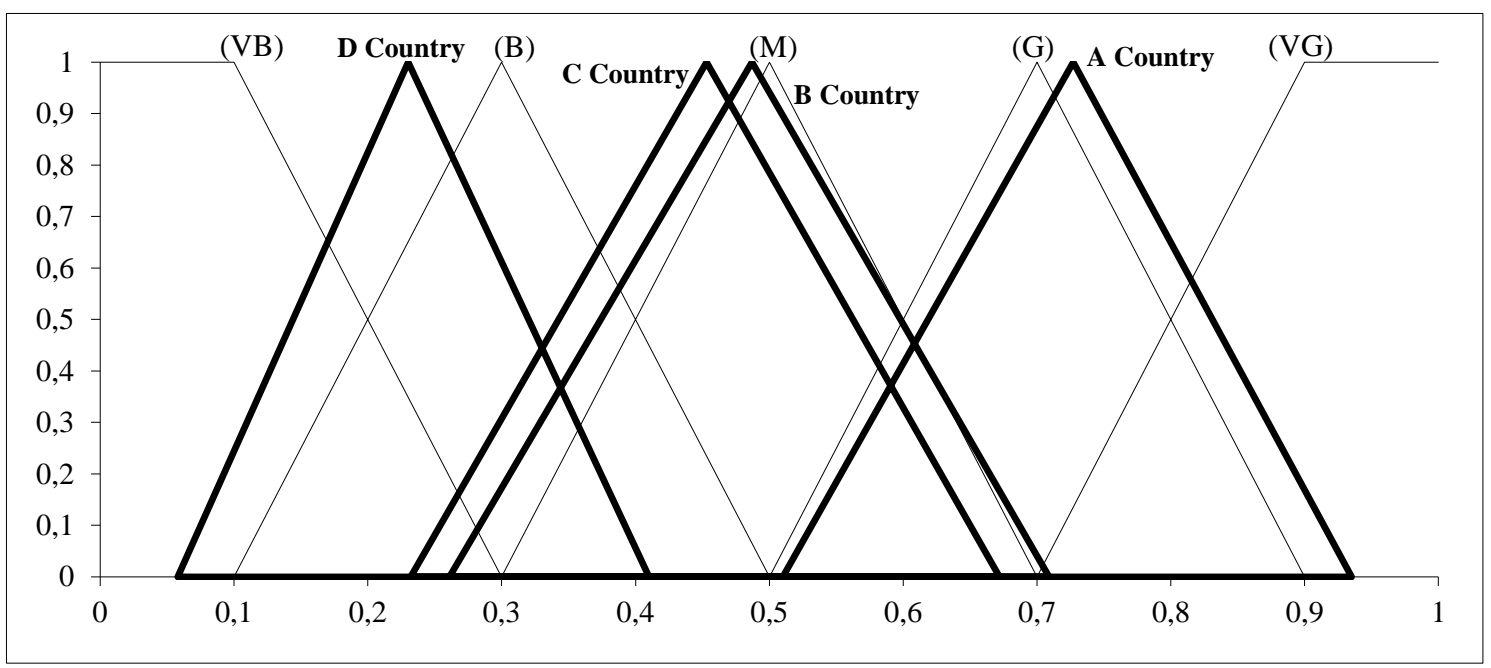

Figure 4. Fuzzy risk management assessment of the countries

\section{CONCLUSIONS}

The fact that disaster risk management is an important concept for countries is revealed with the conducted studies under today's environmental conditions. Today's countries should develop or adopt the models, tools, and techniques that provide opportunities for the assessment and development of disaster risk management skills in order to be ready for a possible disaster. Therefore, in this study, a fuzzy cluster theory-based disaster risk management performance model was explained with a suggested theoretical sample.
In the assessment of the countries selected as samples in the analysis, it was discovered that they give more importance to the post-disaster phase than the pre-disaster phase. It is seen in Table 2 prepared as a result of the conducted analyses that the countries are more successful in the postdisaster phase than the pre-disaster phase in disaster risk management. This situation also explains the why there is so much loss of life and property after disasters. As emphasized in the previous studies; in the event of giving sufficient importance to the pre-disaster phase, the disaster 
performances of the countries will increase, and, in this way, loss of lives and property to occur can be reduced $[2,26]$.

The method suggested and used in this study makes a contribution to the efforts of a country with disaster risks to compare itself to other countries, to determine its risks, and to improve its risk management performance.

\section{REFERENCES}

1. Manilofia, R., 2006. Disaster Communications in the Solomon Islands. ITU/ESCAP Disaster Communications Workshop, 12-15 December 2006. Bangkok. Thailand, 1-12.

2. Xu, J., Lu, Y., 2018. Towards an EarthquakeResilient World: from Post-disaster Reconstruction to Pre-disaster Prevention. Environmental Hazards, 17(4), 269-275.

3. Souza, F., Kushchu, I., 2005. Mobile Disaster Management System Applications-current Overview and Future Potential-proc. Of the First European Mobile Government Conference MGOV2005, Brighton, UK, 10-12 July, mGCI publications, UK, 455-466.

4. Crowe, M., 2015. Texas Flood Tests Use of Drones by Emergency Responders. Emergency Management Magazine Retrieved from http://www.emergencymgmt.com/disaster/Texa s-Flood-Tests-Drones-Emergency-Responders. html Accessed 20.12.2020.

5. Limoncu, S., Almaca, A.B., 2018. Çocuk Merkezli Afet Yönetimi. Megaron. (131), 132-143.

6. Büyükkaracığan, N., 2017. Türkiye'de Kriz and Afet Yönetimi Mevzuatının Değerlendirilmesi. Selcuk University Journal of Social and Technical Researches. 13, 144-193.

7. SH-SSP. 2018. Report, Disaster Management, Space Based Solutions for Developing Nations, University of South Australia and International Space University, 54.

8. Siriporananon, S., Visuthismajarn, P., 2018. Key Success Factors of Disaster Management Policy: A Case Study of the Asian Cities Climate Change Resilience Network in Hat Yai
City, Thailand. Kasetsart Journal of Social Sciences, 39(2), 269-276. https://doi.org/ 10.1016/j.kjss.2018.01.005.

9. Enarson, E., 2000. Gender and Natural Disasters. Crisis Response and Reconstruction Working Paper No: 1, ILO Infocus Programme on Crisis Response and Reconstruction, 73.

10. CRED. 2015, The Human Cost of Natural Disasters. Centre or Research on the Epidemiology of Disasters (Cred), CRED 2015 Research, 57.

11. Dilley, M., Robert, S.C., Uwe, D., Arthur, L.L., Margaret, A., 2005. Natural Disaster Hotspots: a Global Risk Analysis. Washington, DC: World Bank. https://openknowledge. worldbank.org/handle/10986/7376 License: CC BY 3.0 IGO, 148 .

12. Anbarci, N., Escaleras, M., Register, C., 2005. Earthquake Fatalities: The Interaction of Nature and Political Economy. Journal of Public Economics. 89, 9-10. https://doi.org/10.1016/j.jpubeco.2004.08.002

13. Escaleras, M., Anbarci, N., Register, C., 2007. Public Sector Corruption and Major Earthquakes: A Potentially Deadly Interaction. Public Choice, 132, 209-230, 2007. https://doi.org/10.1007/s11127-007-9148-y

14. OECD. 2008. Costs of Inaction of Environmental Policy Challenges Report. OECD 2008.

15. World Bank. 2005. Project Appraisal Document on a Proposed Loan to the Republic of Turkey for an Istanbul Seismic Risk Mitigation and Emergency Preparedness Project. Report 32173-TR.

16. Maly, E., Suppasri, A., 2020. The Sendai Framework for Disaster Risk Reduction at Five: Lessons from the 2011 Great East Japan Earthquake and Tsunami. Int J Disaster Risk Sci. https://doi.org/10.1007/s13753-020-002689.

17. Sena, L., Michael, K.W., 2006. Disaster Prevention and Preparedness. Ethiopia: Ethiopia Public Health Training Initiative, 189.

18. Abulnour, AH., 2014. Towards Efficient Disaster Management in Egypt. HBRC Journal, 10, 117-126. http://dx.doi.org/10.1016/j.hbrcj.2013.07.004. 
19. Sim, T., Lau, J., Cui, K., Wei, H.H., 2019. Post-Disaster Psychosocial Capacity Building for Women in a Chinese Rural Village. Int $\mathbf{J}$ Disaster Risk Sci 10, 193-203. https://doi.org/10.1007/s13753-019-0221-1.

20. Jorge, V.A.M., Granada, R., Maidana, R.G., Jurak, D.A., Heck, G., Negreiros, A.P.F., dos Santos, D.H., Gonçalves, L.M.G., Amory, A.M., 2019. A Survey on Unmanned Surface Vehicles for Disaster Robotics: Main Challenges and Directions. Sensors. 19, 702. https://doi.org/10.3390/s19030702.

21. Kao, C., Liu, S.T., 2001. Fractional Programming Approach to Fuzzy-weighted Average. Fuzzy Sets and Systems. 1203, 435-444 Crossref, ISI.

22. Kale, S., Karaman, E., 2009. Fuzzy Logic Model for Benchmarking Knowledge Management Performance of AEC Firms. Fifth International Conference on Construction in the $21^{\text {st }}$ Century.

23. Guh, Y.Y., Hon, C.C., Lee, E.S., 2011. FuzzyWeighted Average: The Linear Programming Approach Via Charnes and Cooper's Rule. Fuzzy Sets and Systems. 1171, 157-160.

24. Otay, İ., Jaller, M., 2020. Multi-expert Disaster Risk Management \& Response Capabilities Assessment Using Interval-valued Intuitionistic Fuzzy Sets. Journal of Intelligent and Fuzzy Systems. 38(1), 835-852.

25. Đurić, G., Todorović, G., Đorđević, A., Tišma, A.B., 2019. A New Fuzzy Risk Management Model for Production Supply Chain Economicand Social Sustainability. Economic Research-Ekonomska Istraživanja, 32(1), 1697-1715.

26. Özkul, B., Karaman, A.E., 2007. Doğal Afetler için Risk Yönetimi. TMMOB İnşaat Mühendisleri Odas1, Afet Sempozyumu. 